\title{
All-trans retinoic acid-induced myositis during treatment of acute promyelocytic leukemia
}

\author{
Mayorga-Bajo ${ }^{1}$, Ortega-Valín $\mathrm{L}^{* 1,2}$, Fuertes $\mathrm{M}^{3}$, Ramos $\mathrm{F}^{3,4}$ \\ ${ }^{1}$ Department of Pharmacy, Hospital Universitario de León, León, Spain \\ ${ }^{2}$ Grupo de Investigación Interacciones Gen-ambiente-Salud-Universidad de León, León, Spain \\ ${ }^{3}$ Department of Hematology, Hospital Universitario de León, León, Spain \\ ${ }^{4}$ Instituto de Biomedicina (IBIOMED), León, Spain
}

Received: April 9, 2016

DOI: $10.5430 /$ crim.v3n2p46
Accepted: May 3, 2016

Online Published: May 8, 2016

URL: http://dx.doi.org/10.5430/crim.v3n2p46

\begin{abstract}
A 47-year-old man, newly diagnosed with acute promyelocytic leukemia was treated with all-trans retinoic acid (ATRA) and idarrubicin. On day +24 , he presented with fever and swelling in the left lower limb. The US and MRI were compatible with a myositis of tibialis anterior, later confirmed by muscle biopsy. ATRA-induced myositis was suspected. On day +29 , ATRA was discontinued and the patient treated with dexamethasone. The patient improved promptly and ATRA was administered thereafter without any myositis relapse. The Naranjo scale indicated a probable relationship between ATRA and myositis. We herein review the published cases. Re-exposition to the drug seems to be safe for the patient.
\end{abstract}

Key Words: Myositis, All-trans retinoic acid, Acute promyelocytic leukemia

\section{INTRODUCTION}

All-trans-retinoic acid (ATRA) is a natural metabolite of retinol that acts by promoting the terminal differentiation of leukemic cells into phenotypically mature myeloid cells. ATRA is used in combination with chemotherapy, including anthracyclines, as induction, consolidation and maintenance treatment for acute promyelocytic leukemia (APL). This association is able to cure most APL patients making unnecessary to resort to hematopoietic transplantation. The standard daily dose is $45 \mathrm{mg} / \mathrm{m}^{2}$ body surface divided in two equal oral doses. ${ }^{[1]}$

In patients treated with the recommended doses, the most frequent side effects are consistent with the signs and symptoms of the hypervitaminosis A syndrome (nausea and vomiting
$-51 \%$, hyperlipidemia, elevation of aminotransferases $-25 \%$, skin and mucosal dryness $-24 \%$ to $65 \%$, fatigue - more than $25 \%$ - and headaches $-29 \%$ to $90 \%$ ). The most serious side effects are benign intracranial hypertension -pseudotumor cerebri-, acute neutrophilic dermatosis -Sweet's Syndrome, and differentiation syndrome $-25 \%$. Differentiation syndrome is characterized by fever, dyspnea, pulmonary infiltrates, pleural and pericardial effusions, hypotension, edema, weight gain, hepatic, renal and multi-organ failure. Differentiation syndrome is frequently associated with hyperleukocytosis and may be fatal. Treatment with dexamethasone should be initiated promptly and temporary interruption of ATRA should be considered. ${ }^{[1,2]}$

ATRA-induced myositis is a rare adverse effect with an un-

*Correspondence: Ortega-Valín L, PhD; Email: lortegav@ @aludcastillayleon.es; Address: Department of Pharmacy, Hospital Universitario de León, Altos de Nava s/n, ES-24080, León, Spain. 
known incidence and etiology. In general, it shows a predilection for the lower limbs in a bilateral and migratory pattern and responds rapidly to corticosteroid therapy.

We describe a patient who developed fever, pain and swelling in the left lower limb during the third week of treatment for low-risk APL, conducting to the diagnosis of ATRA-induced myositis.

\section{CASE REPORT}

A 47-year-old man, former smoker, with no known drug allergy and a past medical history of Hepatitis A during childhood and dyslipidemia on dietary treatment, was diagnosed with low-risk APL. Induction chemotherapy was started with ATRA $45 \mathrm{mg} / \mathrm{m}^{2} /$ day and idarrubicin $12 \mathrm{mg} / \mathrm{m}^{2} /$ day, days
2, 4, 6 and 8. On day 24, he developed fever associated with pain and swelling in his left lower limb (tibialis anterior muscle). Blood and urine cultures were negative, and the symptoms persisted despite treatment with broad-spectrum antibiotics. MRI (see Figure 1) showed muscle edema involving almost all the muscles of the left leg, with hyperintensity in the T1- and T2-weighted images. An ultrasound scan revealed a synovial leak in the ankle joint. The biopsy of anterior tibial muscle showed ischemic necrosis, as well as inflammatory cells in the interstices and among the muscle fascicles, corresponding to a drug-induced diffuse acute myositis. Upon re-interview, the patient denied any recent exposure to toxic agents, or muscle trauma. Laboratory test results showed creatine kinase $(\mathrm{CK})$ and lactate dehydrogenase (LDH) to be within normal limits.
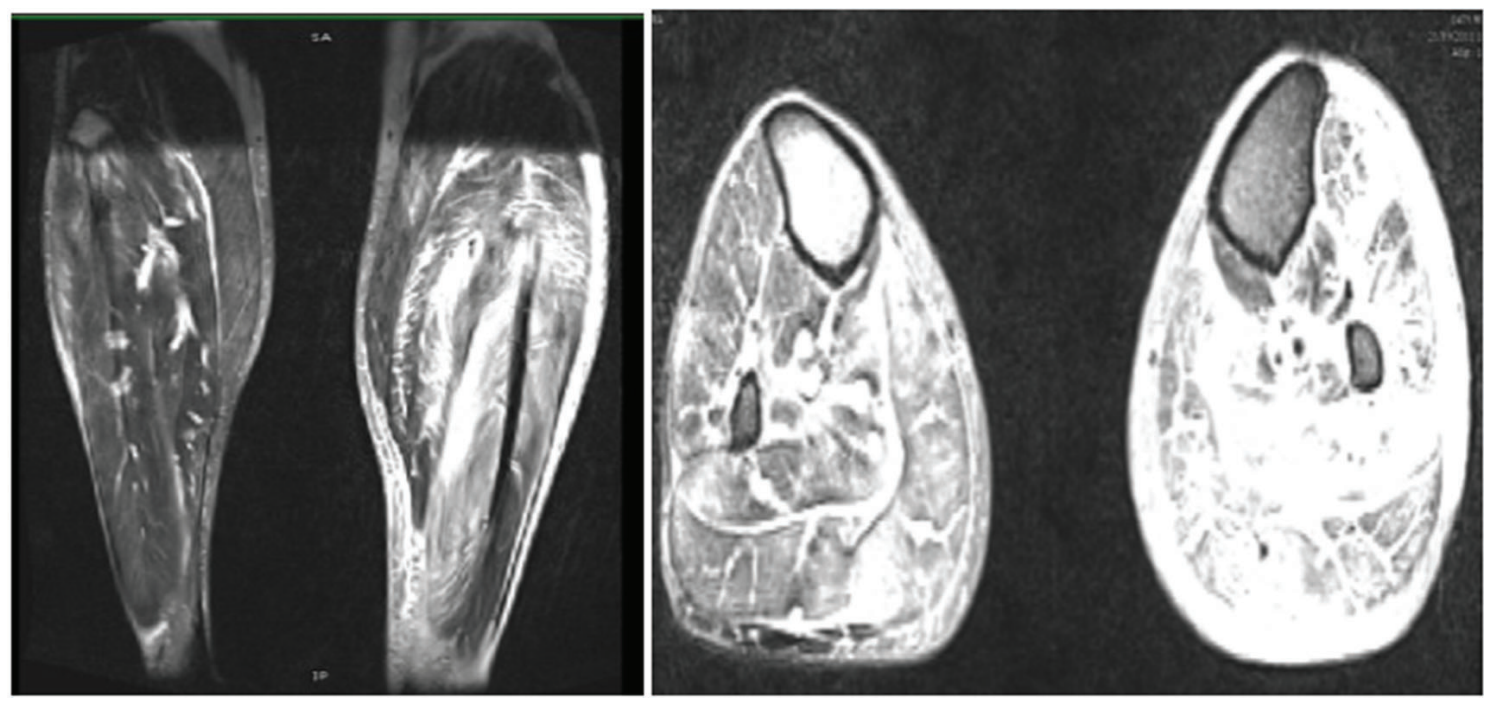

Figure 1. Muscle edema of the left leg

Suspecting ATRA-induced myositis, the drug was discontinued on day 29 , and intravenous dexamethasone $(10 \mathrm{mg} / 12 \mathrm{~h})$ was administered. The patient improved in the next few days, with prompt resolution of fever, disappearance of all inflammatory signs and return of laboratory parameters to normal range. ATRA was restarted on day 40, at full dose and oral dexamethasone was administered for 3 additional days. On day 53 , a complete cytogenetic remission was observed in the bone marrow aspirate and ATRA was discontinued. No relapse in the signs and symptoms of myositis was observed during hospital admission or thereafter.

\section{DISCUSSION}

Acute myositis presents clinically with non-specific symptoms, such as tenderness, pain or muscle weakness and elevated CK levels, but they are not definitive for diagnosis. In most cases, necrosis and/or inflammatory infiltrates may be

Published by Sciedu Press seen in muscle biopsy. Its etiology may be traumatic (myositis ossificans), infectious (see Table 1), drug-induced (see Table 2) or idiopathic. ${ }^{[3-5]}$ A benign form of idiopathic acute myositis can be observed during childhood. Drug-induced myopathies are among the most common causes of muscle disease, although the precise incidence is unknown. They may be caused by several different mechanisms, including direct or indirect muscle toxicity as well as immunologicallyinduced inflammation and range clinically from mild myalgias, with or without weakness, to chronic myopathy with severe weakness, but massive rhabdomyolysis has also been observed. ${ }^{[5]}$

In our patient, other causes and diseases were ruled out by blood and urine culture, serum autoimmune tests, and synovial fluid testing. The drugs that the patient had been exposed to before the onset of myositis were reviewed and 
myositis might also be related to daptomycin, omeprazole or allopurinol. ${ }^{[6-8]}$ While their participation cannot be definitively excluded, the three of them usually present with elevated CK levels, with or without muscle symptoms while our patient presented with serum $\mathrm{CK}$ within normal range despite muscle pain and swelling. In addition, our patient had previously been exposed to omeprazole without having observed any side effects.

Table 1. Infectious Myopathies (Abridged and modified from Grau JM and Miller ML, et al. ${ }^{[3,4]}$ )

\begin{tabular}{llll}
\hline Virus & Bacteria & Fungi & Parasites \\
\hline HIV-1 & Staph. aureus & Candida & T. gondii \\
HTLV-1 & Clostridium & Cryptococcus & Sarcocystis \\
Influenza A and B & Streptococcus & Aspergillus & Trypanosoma \\
Parainfluenza & Yersinia & S. schenkii & E. histolytica \\
Adenovirus & Leptospira & Histoplasma & T. solium \\
Coxsackie & Rickettsia conorii & & Ech. granulosus \\
ECHO & Borrelia burgdorferi & & T. spiralis \\
EBV & Myc. tuberculosis & & Toxocara \\
Arbovirus & T. pallidum & & \\
CMV & Actinomyces & & \\
HBV, HCV & Legionella & & \\
Dengue & E. coli & & \\
VZV & & & \\
HSV & & & \\
Measles virus & & & \\
\hline
\end{tabular}

Table 2. Drug-induced myopathies (Miller et al., modified $\left.^{[5]}\right)$

\begin{tabular}{|c|c|}
\hline Mechanism & Drug \\
\hline $\begin{array}{l}\text { Direct } \\
\text { muscle } \\
\text { toxicity }\end{array}$ & $\begin{array}{l}\text { Alcohol } \\
\text { Cocaine } \\
\text { Glucocorticoids } \\
\text { Lipid-lowering drugs (statins and fibrates) } \\
\text { Antimalarials (chloroquine and hydroxychloroquine) } \\
\text { Colchicine } \\
\text { Zidovudine }\end{array}$ \\
\hline $\begin{array}{l}\text { Immunologic } \\
\text { ally induced } \\
\text { inflammatory } \\
\text { myopathy }\end{array}$ & $\begin{array}{l}\text { D-penicillamine } \\
\text { Interferon alpha }\end{array}$ \\
\hline $\begin{array}{l}\text { Indirect } \\
\text { muscle } \\
\text { toxicity }\end{array}$ & $\begin{array}{l}\text { Diuretics } \\
\text { Alcohol } \\
\text { Cocaine } \\
\text { Phenothiazines and other antipsychotic drugs }\end{array}$ \\
\hline Others & $\begin{array}{l}\text { Tretinoin (ATRA) } \\
\text { Pentazocine } \\
\text { Ipecac (syrup) } \\
\text { Gemcitabine, vincristine and other chemotherapeutic agents } \\
\text { Omeprazole } \\
\text { Allopurinol } \\
\text { Daptomycin }\end{array}$ \\
\hline
\end{tabular}

To the best of our knowledge, 14 cases of ATRA-induced myositis have been reported in the literature. ${ }^{[9-20]}$ They share common features, such as the onset of symptoms during the second to fourth week of induction chemotherapy (10/14), predilection for the lower limbs (14/14), uni- or bilateral involvement (7/14), normal or elevated CK serum levels and fever (11/14). In some cases concomitant Sweet's syndrome or differentiation syndrome is also observed. A single case of cardiac and skeletal involvement has also been communicated in a 45-year-old man receiving ATRA. The patient presented with elevated $\mathrm{CK}$, myoglobin and troponin serum levels as well as abnormalities in his electrocardiogram and echocardiogram. ${ }^{[14]}$ All reported ATRA-induced cases of myositis rapidly responded to corticosteroids (13/14) and/or discontinuation of ATRA (10/14), although three have suffered a relapse. ${ }^{[11,16,19]}$ The similarities between our patient and those described in the literature, along with the laboratory and imaging tests results and his improvement after ATRA discontinuation and corticosteroid therapy, indicate that ATRA was probably responsible for myositis according to the Naranjo scale. ${ }^{[21]}$

In conclusion, ATRA-induced acute myositis is a rare adverse effect during APL induction therapy, but it has distinctive clinical and imaging features that may assist the physician in suspecting it. Its early recognition and management with glucocorticoids and/or ATRA discontinuation would prevent additional patient suffering and complications, as well as prolonged hospitalization and unnecessary treatments and allow for safe completion of ATRA therapy in APL.

\section{Clinical practice points}

Acute myositis usually presents with tenderness, pain or muscle weakness and elevated CK levels, but they are not definitive for diagnosis. In most cases, necrosis and/or inflammatory infiltrates may be seen in muscle biopsy. Its etiology may be traumatic, infectious, drug-induced or idiopathic. We describe a clinical case of acute myositis during the induction treatment with all-trans retinoic acid of a patient diagnosed with acute promyelocytic leukaemia, that was confirmed by muscle biopsy. The Naranjo probability scale indicated a probable relationship between ATRA and myositis in our patient. Finally, we give clues for its early recognition and discuss the differential diagnosis and management of this rare complication of all-trans retinoic acid therapy.

\section{ACKNOWLEDGements}

All authors contributed significantly to this work and the final manuscript was approved by all authors.

\section{CONFlicts OF INTEREST Disclosure}

The authors have declared no conflicts of interest. 


\section{REFERENCES}

[1] Vesanoid. Summary of Product Characteristics. Available from: https://www.medicines.org.uk/emc/medicine/28341. Accessed: July 24, 2015.

[2] Sanz MA, Montesinos P. Tratamiento de la Leucemia Promielocítica Aguda de Nuevo Diagnóstico. Recomendaciones terapéuticas PETHEMA LPA 2012. Available from: http://www.sehh.es/images/stories/recursos/pethem a/protocolos/LAP-2012/1-PROTOCOLO-guia_LPA2012.pdf. Spanish.

[3] Grau JM, Casademont J, Cardellach F. Enfermedades Musculares. In: Rozman C, ed. Farreras-Rozman. Medicina interna. 17th ed. Spain. Elsevier. 2012: 1441-1454.

[4] Miller ML. Viral myositis. In: UpToDate, Targoff IN, Shefner JM (Ed), UpToDate, Waltham MA. Available from: http: //www . uptodate.com/contents/viral-myositis? source=preview\&search=Viral+myositis\&language=en -US\&anchor=H95774402\&selectedTitle=1 15. Accessed: February 12, 2016.

[5] Miller ML. Drug-induced myopathies. In: UpToDate, Targoff IN, Shefner JM (Ed), UpToDate, Waltham MA. Available from: http://www.uptodate.com/contents/drug-induced myopathies?source=related_link. Accessed: February 12, 2016.

[6] Daptomycin. Summary of Product Characteristics. Available from: http://www.ema.europa.eu/docs/en_GB/document_librar y/EPAR___Product_Information/human/000637/WC50003 6049.pdf. Accessed: July 24, 2015.

[7] Visruthan NK, Boo PK, Kader A, et al. Omeprazole-induced myositis in a Child receiving triple therapy for Helicobacter pylori Infection. J Pediatr Gastroenterol Nutr. 2012; 55: 338-9. PMid:22437473 http://dx.doi.org/10.1097/MPG.0b013e318255117b

[8] Terawaki H, Suzuki T, Yoshimura K, et al. A case of allopurinolinduced muscular damage in a chronic renal failure patient. Nihon Jinzo Gakkai Shi. 2002; 44: 50-3. PMid:11925947 http: //dx.doi.org/10.2329/perio.44.Supplement2_50

[9] Miranda N, Oliveira P, Frade MJ, et al. Myositis with tretinoin. Lancet. 1994; 15: 1096. http://dx.doi.org/10.1016/S0140 -6736 (94) 91756-6

[10] Christ E, Linka A, Jacky E, et al. Sweet's syndrome involving the musculoskeletal system during treatment of promyelocytic leukemia with all-trans retinoic acid. Leukemia. 1996; 10: 731-34 PMid:8618455

[11] Van der Vliet HJ, Roberson AE, Hogan MC, et al. All-trans-retinoic acid-induced myositis: a description of two patients. Am J Hematol 2000; 63: 94-8. http://dx.doi.org/10.1002/(SICI) 1096-8 652 (200002) 63:2<94: :AID-AJH7>3.0.CO;2-H

[12] Martínez-Chamorro C, Martínez E, Gil-Fernández JJ, et al. ATRAinduced myositis in induction therapy of acute promyelocytic leukemia. Haematologica. 2002; 87: ECR08. PMid:11836177

[13] Kannan K, Khan HA, Jain R, et al. All-trans retinoic acid-induced myositis. Br J Haematol. 2005; 131: 560. PMid:16351631 http: //dx.doi.org/10.1111/j.1365-2141.2005.05684.x

[14] Fabbiano F, Magrin S, Cangialosi C, et al. All-trans retinoic acid induced cardiac and skeletal myositis in induction therapy of acute promyelocytic leukaemia. Br J Haematol. 2005; 120: 4445. PMid:15842672 http://dx.doi.org/10.1111/j.1365-214 1.2005.05465.x

[15] Chan KH, Yuen SLS, Joshua D. A case of all-trans retionoic acidinduced myositis in the treatment of acute promyelocytic leukaemia. Clin Lab Haematol. 2005; 27: 399-401. PMid:16307543 http: //dx.doi.org/10.1111/j.1365-2257.2005.00729.x

[16] Citak FE, Ezer U, Akkaya E, et al. All-trans-retinoic acid-induced myositis in a child with acute promyelocytic leukemia. Haematologica. 2006; 91(8 Suppl): ECR35. PMid:16923519

[17] Oliveira AC, Domingo-Domenech E, Arnan M, et al. All-trans retinoic acid-induced myositis in a case of acute promyelocytic leukaemia. Int J Lab Hem. 2008; 30: 254-5. PMid:18205843 http://dx.doi.org/10.1111/j.1751-553X.2007.00933.x

[18] Manglani MV, Balamurugan P. All-trans-retinoic acid (ATRA) induced myositis. Indian Pediatr. 2009; 46: 912-3. PMid:19887701

[19] Yu W, Burns CM. All-trans retinoic acid-induced focal myositis, synovitis, and mononeuritis. J Clin Rheumatol. 2009; 15: 358 60. PMid:20009973 http://dx.doi.org/10.1097/RHU.0b013 e31818866d8

[20] Pecker LH, Tsai J, Angiolillo A. All-trans retinoic acid-induced inflammatory myositis in a patient with acute promyelocytic leukemia. Pediatr Radiol. 2014; 44: 1039-41. PMid:24658375 http://dx.d oi .org/10.1007/s00247-014-2951-y

[21] Naranjo CA, Busto U, Sellers EM, et al. A method for estimating the probability of adverse drug reaction. Clin Pharmacol Ther. 1981; 30: 239-45. PMid:7249508 http://dx.doi.org/10.1038/clpt. 19 81.154 